\title{
Food Self-Sufficiency: Opportunities and Challenges for the Current Food System
}

\author{
Jean Pierre Enriquez* \\ Masters Program in Sustainable Tropical Agriculture, Graduate Department, Zamorano University, Tegucigalpa
}

*Corresponding author: Jean Pierre Enriquez, Masters Program in Sustainable Tropical Agriculture, Graduate Department,

Zamorano University, Tegucigalpa, Email: jean.enriquez.2018@alumni.zamorano.edu

\section{ARTICLE INFO}

Received: 幽 October 02, 2020

Published: 幽 October 14, 2020

Citation: Jean Pierre Enriquez. Food SelfSufficiency: Opportunities and Challenges for the Current Food System. Biomed J Sci \& Tech Res 31(2)-2020. BJSTR. MS.ID.005061.

Keywords: Food Production;SelfSufficiency Index;Food Security; Food Energy Produced

Abbreviations: FSS: Food SelfSufficiency; SSR: Self-Sufficiency Ratio; DEP: Dietary Energy Production
ABSTRACT

Food Self-Sufficiency (FSS) is defined as the ability of a household or region to maintain its own food requirements, which can be measured at different levels, and it began to take relevance around 2007-2008 food price crisis. The FSS all-together with food price volatility has become a high priority political agenda for governments all around the word, helping them determine the number of households that can supply their food by own production. Generally, a population depends on natural resources and available foods to meet their daily food demand, so a region can increase the stability of its food system by building its own FSS. Moreover, the pre-technological urbanism, consider the FSS as a strategic factor in the advancement and independence in localities. Since food systems operate at different scales, one way to reduce risks is to get smaller space units to maintain a degree of FSS. Therefore, it can ensure a level of FSS by supporting the agricultural sector focusing on improving production efficiency in countries with food insecurity. It is also necessary to work on research that allows the development of production models with the presence of FSS to avoiding isolating them from the reality in which it is developed

\section{Introduction}

FSS and price volatility have become a high priority political agenda for governments [1]. Developing governments face the conflict of agricultural policy between fully open trade and closed borders for food security and cheaper food [2]. Food procurement in a country could be stabilized creating a network of commercial partners working in a free-trade regime. However, regional economic integration increased recently, driving individual importers away from FSS [3].Increasing crop diversity is an agroecological approach to improve FSS, so small producers can maintain the stability of their food systems, reducing the risks of stress, pest outbreaks or droughts [4]. A region can increase the stability of its food system by building its own FSS [5].Food production is a starting point in the analysis of sovereignty and food security. Revenue generation through efficient field production provides a real productivity base [6]. The traditional agricultural production of production systems determines access to food and obtaining complementary income through the sale of products and by-products; this being considered as the result of the integration of life strategies [7].
FSS is defined as the ability of a household or region to maintain its own food requirements which can be measured at different levels [8]. In a narrow context, it determines the number of households that can supply their food from their own production, reporting the number of months of the year where households are self-sufficient in food. To measure the FSS, information on crop yields is needed as well as food production in the region under study [9].

For a population to meet their daily needs, it usually depends on natural resources and wild foods [10]. Globally, $52 \%$ of the countries produced insufficient calories per capita in 2005; however, $80 \%$ of all countries quantified as importers of at least $500 \mathrm{kcal} /$ capita / day [11]. For the pre-technological urbanism, food self-sufficiency is considered a strategic factor in the advancement and independence of the localities [12]. Global food production continues to increase, making FSS at a country level, steadily declining. Also, urbanization trends and increased population density have been correlated with these decreases [13].There is a concern because of the increasing 
demand, climate, and environmental changes threaten turning the food more expensive and difficult to produce [14]. Therefore, vulnerability is observed in food systems due to population growth, water scarcity, and soil degradation [4]. Since food systems operate at different scales, one way to reduce risks on a large scale is to ensure that smaller space units maintain a degree of FSS [15].It is essential to propose the application of technological innovations, urban agriculture, production in greenhouses, and zero tillage $[16,17]$. These technologies have the capacity to increase food production, releasing pressure on land, thus controlling resource depletion and environmental degradation [18]. In the future, it is necessary to dispel the conflicts generated between farmers and urban dwellers. People should also create a more holistic social awareness of the importance of restoring agriculture in places around cities [19]. One way to ensure, at least partially, FSS is to support the agricultural sector, focused on improving production efficiency, especially in countries with food insecurity [20].

One way to measure the levels of FSS of countries is through food energy production per capita [11]. More developing countries have supported the food sovereignty agenda in their national legislation including Bolivia, Ecuador, Malí, Nepal, Nicaragua, Senegal y Venezuela [21].The drivers of food sovereignty have given significant support to greater food self-sufficiency based on agroecology methods to increase the resilience of local food systems [22]. For that reason, this article has as objective to review the challenges and opportunities of the FSS based on the last twenty years scenario.

\section{Research strategy and selection}

Publications included in this research were those written in English and Spanish focused on FSS. Hence the keywords for the search were self-sufficiency index, food production, food availability, and food energy produced. The review was carried out through extensive searches of literature in the databases Elsevier, Springer Link, and Academic Google. The content of the documents was revised and selected based on their direct or indirect relevance to this review. Additional references included were, which were found throughout the review process in some of the selected documents, relevant to the content of this article.According to the bibliographic evidence from the year 2000 , where more than $83 \%$ of the selected publications are within the last ten years, four major topics where identified that encompass the challenges that FSS face: the FSS in the population, global experiences with FSS, interventions and small communities, and climate change. It was also identified three opportunities: Crops diversity and agroecology; self-supply, environmental sustainability and economy; and urban selfsufficiency.

\section{Overview of food self-sufficiency}

Food self-sufficiency is thermodynamically defined as the national production of enough calories per capita. This definition assigns the per capita calorie needs of each local population [23]. In this way, countries are informed, if they are producers, which countries produce more than per capita needs, or if they are consumers, and which countries produce less than the per capita needs within the food supply system [19]. Self-sufficiency represents risks of food insecurity when more than $25 \%$ of the food components of the diet necessary to satisfy the needs of the population come from importation [24]. Conversely, food selfsufficiency is considered a waste since the farmers deprived of income as a result of potentially exportable foods not being sold abroad, affecting food economy and security [25].Seventy-seven percent of the countries worldwide are not self-sufficient in terms of domestic calorie production [26]. The countries with high food selfsufficiency have large areas for agriculture, productive agriculture, and low-density rural populations, which produce food surpluses. On the other hand, there are small and highly urbanized countries, being extremely vulnerable to sociopolitical turmoil as well as the environmental catastrophe resulting from limiting arable land and net food deficits [13]. The strategy based on food self-sufficiency that limits the role of food imports took relevance in the 2007-08 food price crisis [2]. At the time, many countries considered it to be one of the key priorities for their agri-food policies [27].

The Self-Sufficiency Ratio (SSR) is defined as the percentage of food consumed that a country produces [28]. An equation concerning food production and trade is used to calculate the SSR: Production x 100 / (Production + Imports - Exports). Net foodexporting countries are generally self-sufficient according to the SSR and the food energy produced or Dietary Energy Production (DEP). In contrast, net food-importing countries are not considered self-sufficient based on such measures [29]. Most SSR analyses focus on key staple crops, such as starch cereals and tubers, offering an approximation of a country's food self-sufficiency [2].

\section{Challenges}

\section{Food Self-Sufficiency in the Population}

In the face of an imminent decline in natural resources and population increase, it is necessary to create substantial socioeconomic and biophysical actions to ensure food security [30,31]. Table food supply is a common indicator of food security, at least from an individual perspective [13]. At the beginning, food security focused on food reserves that allowed survive to famine. The increase in the level of human development helped discover that insufficient purchasing power of the poorest segments of the population is another factor for food insecurity [27]. Supporters of FSS defend the political right of states to insulate themselves from the vagaries of global food markets, increasing their dependence on domestic food production [2].In 2010, the world's food production per capita was $5359 \mathrm{kcal}$ per person per day, surpassing a $2500 \mathrm{kcal}$ necessary for a healthy life [28]. Considering food waste, animal feed, and other uses of food crops, approximately 2870 kcal per 
capita per day was available for food consumption worldwide by 2011, exceeding the threshold above which FSS is considered [32]. Between 1965 and 2005, around 25\% of the world's population lived in countries that produced more than $2500 \mathrm{kcal}$ per person per day, while $75 \%$ resided in countries that produced below that threshold [11]. Considering the percentage of countries that are self-sufficient, rather than the percentage of the population, it was estimated that around $77 \%$ of the world's countries have a caloric deficit [26].The degree of food self-sufficiency will provide greater stability and resistance to global crises in regions with greater selfsufficiency. Similarly, a household with FSS will be more protected to regional and local changes [15]. Each country faces different scenarios regarding its ability to obtain food for its population, depending on its food productive capacity, import and distribution [29].

\section{Global Experiences with Food Self-Sufficiency}

FSS has become increasingly important to the political agenda in several countries, especially after the high volatility of food prices between 2007 and 2008 crisis [29-33]. Countries considered self-sufficient at the national level may have a percentage of their population with problems of hunger and malnutrition. However, those countries can produce enough crops such as grains, but they may also need to import significant amounts of fruits and vegetables to achieve a healthy diet [29]. Nowadays, around sixty-six countries cannot be self-sufficient due to natural resource constraints, limited availability of farmland, water, and soil fertility [34].Approximately one billion people in Asia and Africa could become less vulnerable to global impacts if their local FSS increased [35]. The SSR of Africa had decreased from $100 \%$ in 1961 to $80 \%$ in 2007 [36,37], with food imbalances also found between rural and urban areas [3]. Therefore, African countries should seek to make food selfsufficiency less susceptible to changes in foreign food supplies [38]. In Asia, the surplus production allows rural people to generate income to battle poverty [38]. It is, therefore, suspected that FSS has changed in Asian countries as a result of wage increases and other factors returning to less affordable agriculture [39].

In Rusia, food security is defined as a reduction in food imports and not simply an adequate intake of food in order to live healthy, since overall food security and FSS influence food trade policy [33]. For this reason, their level of food self-sufficiency increases as food products of foreign origin withdraw from the food market in the form of an economic recession, ruble depreciation and rising import price [40].In Mexico, food security and nutrition intervention strategies in indigenous communities seek to ensure family FSS and promote the consumption of various diets based on locally produced foods [41]. Self-sufficiency, used as a strategy to achieve food security, is an alternative for regions with food shortages [42] Egypt's government has increased its wheat self-sufficiency to insulate local markets from global supply and demand impacts [1]. On the other hand, in Spain, the potential for FSS of horticultural products from Mataró (Barcelona) was evaluated, where there is a potential for self-sufficiency in fresh vegetables and potatoes of $88.7 \%$ [43]. For its part, in the Czech Republic, FSS is ensured by up $20 \%$ of the decrease in yield for most crops [44]. While in the United States, a "new food pantry" program aims to develop selfsufficiency in the poorest areas of the United States by providing emergency food assistance [45].

\section{Interventions and Small Communities}

Family nutrition, unable to achieve diversity and quality, becomes monotonous and unbalanced; thus, food security could be affected by poverty [46]. One of the most worrying factors is the social component that encompasses poverty, unemployment, and inequality [47]. Approximately, 39\% of the world's population is overweight, while about $13 \%$ are obese $[48,49]$. Nearly 40 million Latin American people have insufficient food intake, while another 360 million are overweight or obese [50].In Ecuador, indigenous families in rural areas have orchards as a job opportunity that at the same time provides them with food. Therefore, this generates savings in the home, as well as additional income from the sale of surpluses achieving stability in food availability and better food conditions [49]. In Seville, Spain, a community called "Los Portales" was developed to create innovations in areas such as organic agriculture, holistic education, natural medicine, art, clean energies, economy, personal development in search of greater sustainability and self-sufficiency [51]. In contrast, there are also the ecovillages to seek to recover the bonds of community between people heading towards sustainability. These projects find new ways to relate with the environment through logic of self-management and selfsufficiency in different fields: food, construction, mobility, energy, among others [52].

A condition where a cluster of factors (diversity of agricultural species, producer age, their schooling, number of members of the domestic unit, migration and geographical location) play an important role in the family FSS [7]. The livelihood of these small producers in southwestern Madagascar is highly susceptible to biotic and abiotic crises, due to their high dependence on natural resources, so they need to reinforce initiatives to improve the management of productive areas and FSS [9].

\section{Climate Change}

The design of new cities, as well as the transformation of existing cities considering sustainability criteria, is paramount to address climate problems [53]. In different parts of the world, climate change will negatively affect food production, especially in sub-Saharan Africa, where a high percentage of the population faces chronic hunger [54].There are also environmental consequences in countries that dominate export markets in certain crops $[55,56]$. Crops, such as maize, are generally associated with a high use of agrochemicals and irrigation [57]. Other crops, such as palm oil and soy, are often associated with deforestation [58], contributing to the 
negative effects of climate change.In the current climatic conditions, in southern Mali, it was achieved to meet the food needs of large and medium-sized farms, while small farms were the opposite. On the other hand, under current farming practices and the future of climate, food availability decreased for all types of farms, but large farms still achieve FSS. What this shows is that in order to achieve a family FSS, it is necessary to improve current crop management strategies [59].

\section{Opportunities}

\section{Crop Diversity and Agroecology}

If farmers diversify their crops, the probability of harvest success will increase, at least partially in the event of a mishap; however, stable and diverse agroecosystems may not be economically efficient. The production of highly specialized staple food monocultures is highly productive, but there is a risk that crops are fragile as they are produced on marginal lands by small subsistence farmers [60].The probability of a household being self-sufficient increases with the number of crops grown, so crop diversification serves as a strategy for improving food selfsufficiency at the family level [4]. The cornfield known as "Milpa" in its original area in Latin America, is a family garden or backyard of small-scale production considered as a plant genetic reservoir close to the house that forms an economic unit of self-consumption at the door of the home [61]. The right to food is not the emphasis of food sovereignty, but also the right to produce food. This concept is based on the role of family farming, organic production methods, and a fair distribution of productive inputs [62].

\section{Self-Supply, Environmental Sustainability and Economics}

In the context of discussions on trade and food security, selfsufficiency generally refers to countries seeking to produce all or most of their own food for domestic consumption. In another perspective, from an autarkic position, FSS can be defined as a country that closes its borders to all food trade, concentrating its resources in the agricultural sector to produce national food requirements [29]. The origin of food is related, among other factors to family economic income, proximity to the supply place, the variety of products, price and freshness of foods [63].Agriculture is essential for the supply of food, as well as for the basic needs of human beings [13]. This right is guaranteed by achieving the FSS to achieve new forms of sustainable management available among producers. The challenge is to identify and transfer them through the establishment of agroecological lighthouses to restore low yields [64]. Hence, in times of scarcity, countries that depend on of food imports face a disadvantage in terms of food security, compared to states that meet food demands with local crop production [65].

\section{Urban Self-sufficiency}

Nowadays, urban demographic change correlates with declining FSS. In 1965, predominantly rural countries with low to intermediate population densities produced enough food for their population; consequently, only two of the more urbanized countries Bermuda and Malta (> 75\% urban) had food production deficits. In 2010, in less than half a century, countries with dense and highly urbanized populations had deficits in their food production [13]. European urban consumption centers have the advantage of being connected to their peri-urban and rural agricultural production areas [66]. The informal food system, under which active urban gardeners produce, consume, and share their products, is geographically highly localized, creating short food circuits and energy flows. The gardens and the food supply are essential parts of the urban food system [67].The urban centers, which usually have local food deficits, are surrounded by large areas, where neighboring communities also cannot meet their demand for food through domestic production [68]. Peri-urban agriculture has the potential to create local circular food economies, reusing humanderived nutrients as fertilizers, also contributing access to fertilizers in developing countries [69]. Peri-urban agriculture is essential to avoid food lost and wastes as it reduces the distance from the field to the table [70]. However, research in peri-urban agriculture has developed in a few cities $[68,71]$.

\section{Conclusion}

It is necessary to direct research developing production models that possess FSS, which should not be isolated from the reality of the country in which it is growing so that, when taking it to a real-world scenario, the results are just as efficient.FSS does not necessarily imply that the daily food needs of the population are filled equally, but it is a challenge that needs to be addressed and discussed in the government policies of those nations that emphasize food self-sufficiency.It is important to consider that the security of FSS cannot be isolated, both the academy and the government entities must take into account these principles to face and prevent public health problems of hunger, malnutrition, overweight, obesity and chronic diseases.

\section{Acknowledgement}

I would like to thank the Master's Program in Sustainable Tropical Agriculture for financial support. Also, I would like to thank Dr. Gloria Arevalo, and Dr. Adriana Hernandez at Zamorano University for assistance in this manuscript.

\section{References}

1. Tanaka T (2018) Agricultural self-sufficiency and market stability: a revenue-neutral approach to wheat sector in Egypt. Journal of Food Security 6(1): 31-41.

2. Clapp J (2017) Food self-sufficiency: Making sense of it, and when it makes sense. Food policy 66: 88-96.

3. Tanaka T, Hosoe N (2011) Does agricultural trade liberalization increase risks of supply-side uncertainty? Effects of productivity shocks and export restrictions on welfare and food supply in Japan. Food Policy 36(3): 368-377.

4. Kc K B, Pant L P, Fraser E D, Shrestha P K, Shrestha D (2016) Assessing links between crop diversity and food self-sufficiency in three 
agroecological regions of Nepal. Regional Environmental Change 16(5): 1239-1251.

5. Bucagu C, Vanlauwe B, Van Wijk M T, Giller K E (2014) Resource use and food self-sufficiency at farm scale within two agro-ecological zones of Rwanda. Food security 6(5): 609-628.

6. Falcon W P, Naylor R L (2005) Rethinking food security for the twentyfirst century. American Journal of Agricultural Economics, 87(5): 1113-1127.

7. Barrientos S D L, Magana M A (2016) Milpa and backyard contribution to self-sufficiency food in Mayan communities of Yucatan. Social Studies 24(47): 182-203.

8. Coates J (2013) Build it back better: Deconstructing food security for improved measurement and action. Global Food Security 2(3): 188-194.

9. Noromiarilanto F, Brinkmann K, Faramalala M H, Buerkert A (2016) Assessment of food self-sufficiency in smallholder farming systems of south-western Madagascar using survey and remote sensing data. Agricultural Systems 149: 139-149.

10. Andriamparany J N, Brinkmann K, Jeannoda V, Buerkert A (2014) Effects of socio-economic household characteristics on traditional knowledge and usage of wild yams and medicinal plants in the Mahafaly region of south-western Madagascar. Journal of ethnobiology and ethnomedicine 10(1): 82 .

11. Porkka M, Kummu M, Siebert S, Varis O (2013) From food insufficiency towards trade dependency: a historical analysis of global food availability. PloS one 8(12).

12. Oyón J L (2015) The city from consumption: Kropotkin and the anarchist Commune in The Conquest of Bread. Urban.

13. Schramski J R, Woodson C B, Steck G, Munn D, Brown J H (2019) Declining Country-Level Food Self-Sufficiency Suggests Future Food Insecurities. Biophysical Economics and Resource Quality 4(3): 12.

14. Fedoroff N V, Battisti D S, Beachy R N, Cooper P J, Fischhoff D A, et al. (2010) Radically rethinking agriculture for the $21^{\text {st }}$ century. science 327(5967): 833-834.

15. Fraser E D, Mabee W, Figge F (2005) A framework for assessing the vulnerability of food systems to future shocks. Futures 37(6): 465-479.

16. Specht K, Siebert R, Hartmann I, Freisinger U B, Sawicka M, et al. (2014) Urban agriculture of the future: an overview of sustainability aspects of food production in and on buildings. Agriculture and human values 31(1): 33-51.

17. Opitz I, Berges R, Piorr A, Krikser T (2016) Contributing to food security in urban areas: Differences between urban agriculture and peri-urban agriculture in the Global North. Agriculture and Human Values 33(2): 341-358.

18. Chartres C J, Noble A (2015) Sustainable intensification: overcoming land and water constraints on food production. Food security 7(2): 235245 .

19. Taylor E, Butt A, Amati M (2017) Making the blood broil: Conflicts over imagined rurality in peri-urban Australia. Planning Practice \& Research 32(1): 85-102.

20. Collier P, Dercon S (2014) African agriculture in 50 years: smallholders in a rapidly changing world? World development 63: 92-101.

21. Shattuck A, Schiavoni C M, Van Gelder Z (2015) Translating the politics of food sovereignty: Digging into contradictions, uncovering new dimensions. Globalizations 12(4): 421-433.

22. Wittman H, Desmaris A A, Wiebe N (2010) Food Sovereignty: reconnecting food, nature and community. Halifax USA Fernwood Publishing.

23. Timmons D, Wang Q Lass D (2008) Local foods: Estimating capacity. Journal of extension 46(5): 1-11.
24. Curiel R (2013) MasAgro por la seguridad alimentaria y el desarrollo agrícola sustentable en México. Claridades Agropecuarias 237: 9-18.

25. Naylor R L, Falcon W P (2010) Food security in an era of economic volatility. Population and development review 36(4): 693-723.

26. Davis K F, D Odorico, P Rulli M C (2014) Moderating diets to feed the future. Earth's Future 2: 559-565.

27. Baer Nawrocka A, Sadowski A (2019) Food security and food selfsufficiency around the world: A typology of countries. PloS one 14(3).

28. (2012) FAO, FAO Statistical Yearbook 2012 -World Food and Agriculture.

29. Clapp J (2015) Food Self-Sufficiency and International Trade: A False Dichotomy? State of Agricultural Commodity Markets-In Depth. FAO Rome.

30. Tilman D, Balzer C, Hill J, Befort B L (2011) Global food demand and the sustainable intensification of agriculture. Proceedings of the national academy of sciences 108(50): 20260-20264.

31. Cole M B, Augustin M A, Robertson M J, Manners J M (2018) The science of food security. npj Science of Food 2(1): 1-8.

32. (2015) FAO, FAO Statistical Pocketbook World Food and Agriculture.

33. Wegren S K, Elvestad C (2018) Russia's food self-sufficiency and food security: an assessment. Post-Communist Economies 30(5): 565-587.

34. Fader M, Gerten D, Krause M, Lucht W, Cramer W (2013) Spatial decoupling of agricultural production and consumption: quantifying dependences of countries on food imports due to domestic land and water constraints. Environmental Research Letters 8(1): 014046.

35. Pradhan P, Lüdeke M K, Reusser D E, Kropp J P (2014) Food selfsufficiency across scales: how local can we go? Environmental science \& technology 48(16): 9463-9470.

36. Luan Y, Cui X, Ferrat M (2013) Historical trends of food self-sufficiency in Africa. Food Sec 5(3): 393-405.

37. Van Ittersum, M K Van Bussel, L G Wolf, J Grassini, P Van W art, et al. (2016) Can sub-Saharan Africa feed itself? Proceedings of the National Academy of Sciences 113(52): 14964-14969.

38. Bishwajit G, Sarker S, Kpoghomou M A, Gao H, Jun L, et al. (2013) Self-sufficiency in rice and food security: a South Asian perspective. Agriculture \& Food Security 2(1): 10.

39. Otsuka K, Liu Y, Yamauchi F (2013) Factor endowments, wage growth, and changing food self-sufficiency: Evidence from country-level panel data. American Journal of Agricultural Economics 95(5): 1252-1258.

40. Erokhin V (2017) Self-sufficiency versus security: How trade protectionism challenges the sustainability of the food supply in Russia. Sustainability 9(11): 1939.

41. González Cortés C, Barriga Martínez F D (2019) Food and nutrition security in a community indigenous to Mexico. Rev Esp Nutr Comunitaria $25(3)$.

42. Martínez Salvador L (2016) Food security, self-sufficiency and availability of amaranth in Mexico. Developmental problems 47(186): 107-132.

43. Ujaque D S, Cerviño F (2017) Food self-sufficiency and ecological production in the agricultural area of the "Cinc Sènies" of Mataró. Agroecological Journal of Disclosure (30): 48-49.

44. Pulkrábek J, Pacek L, Č́́tek J, Stupka R, Pračke K, et al. (2019) Regional food and feed self-sufficiency related to climate change and animal density-a case study from the Czech Republic. Plant, Soil and Environment 65(5): 244-252.

45. Martin K S, Wu R, Wolff M, Colantonio A G, Grady J (2013) A novel food pantry program: food security, self-sufficiency, and diet-quality outcomes. American journal of preventive medicine 45(5): 569-575. 
46. (2018) World Health Organization WHO, Malnutrición.

47. Acuña I T, Murillo M P, Salinas F A (2013) Poverty, Livelihoods and Food Security. The Case of the Municipalities of Aguadas and Palestina, Caldas, Colombia. Sociedad y economía (24): 231-262.

48. Malo Serrano M, Castillo N, Pajita D (2017) Obesity in the world. Annals of the Faculty of Medicine 78(2): 173-178.

49. Guerrero E A, Álvarez L S J, Jaramillo N D C F, Durazno R C, Mora E D C (2019) Community intervention to promote food self-sufficiency: an experience in the Loja canton, Ecuador. Agri Food 25(48): 103-116.

50. (2017) Eradicating hunger in Latin America and the Caribbean by 2030 is becoming increasingly unlikely.

51. Camarero L (2017) Farm workers and land families. Snapshots of desegregation. Ager: Journal of depopulation and rural development studies (23): 163-195.

52. Ruiz F (2019) The ecovillage network: restocking, self-government, selfmanagement and food self-sufficiency. PH: Bulletin of the Andalusian Institute of Historical Heritage 27(98): 24-28.

53. Rosenzweig C, Solecki W D, Romero Lankao, P Mehrotra, S Dhakal S, et al. (2018) Climate change and cities: Second assessment report of the urban climate change research network. Cambridge University Press.

54. Lobell D B, Burke M B, Tebaldi C, Mastrandrea M D, Falcon W P, et al. (2008) Prioritizing climate change adaptation needs for food security in 2030. Science 319(5863): 607-610.

55. Mac Donald G K, Brauman K A, Sun S, Carlson K M, Cassidy E S, et al. (2015) Rethinking agricultural trade relationships in an era of globalization. BioScience 65(3): 275-289.

56. Hertel T W, Ramankutty N, Baldos U L C (2014) Global market integration increases likelihood that a future African Green Revolution could increase crop land use and $\mathrm{CO} 2$ emissions. Proceedings of the National Academy of Sciences 111(38): 13799-13804.

57. Nadal R, Wise T A (2004) The environmental costs of agriculture trade liberalization: Mexico-US Maize Trade Under NAFTA. In Global Development and Environment Institute Tufts University.

58. Vijay V, Pimm S L, Jenkins C N, Smith S J (2016) The impacts of oil palm on recent deforestation and biodiversity loss. PloS one 11(7).

59. Traore B, Descheemaeker K, Van Wijk, M T Corbeels, M Supit, et al (2017) Modelling cereal crops to assess future climate risk for family food self-sufficiency in southern Mali. Field Crops Research 201: 133145.

ISSN: 2574-1241

DOI: 10.26717/BJSTR.2020.31.005061

Jean Pierre Enriquez. Biomed J Sci \& Tech Res

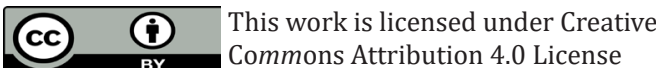

Submission Link: https://biomedres.us/submit-manuscript.php
60. Kim K, Chavas J P, Barham B, Foltz J (2012) Specialization, diversification, and productivity: a panel data analysis of rice farms in Korea. Agricultural Economics 43(6): 687-700.

61. García X M, Caamal A, Ku B K, Xool E C, Armendáriz I, et al. (2003). Peasant agriculture of the Mayans in Yucatan. LEISA Revista de Agroecología 19: 7.

62. Pieters H, Vandeplas A, Guariso A, Francken N, Sarris A, et al. (2012) Perspectives on relevant concepts related to food and nutrition security.

63. Schnettler B, Obreque B, Cid E, Mora M, Miranda H, et al. (2010) Influence of origin country in the purchase decision for foodstuffs: a study of consumers of different ethnic groups in Chile. Revista Latinoamericana de Psicología 42(1): 119-130.

64. Huato M Á D, León A C, Sangerman Jarquín, D M Reyes, L L Montiel, et al. (2019). Producer-Innovative And Food Self-Sufficiency Model For Milperos De Secano: Sustainable Public Policy Proposal. Scripta Nova 23(608).

65. Davis K F, Gephart J A, Gunda T (2016) Sustaining food self-sufficiency of a nation: The case of Sri Lankan rice production and related water and fertilizer demands. Ambio 45(3): 302-312.

66. Sali G, Corsi S, Monaco F, Mazzocchi C, Glavan M, et al. (2014) Urbanrural relationships in feeding metropolis: A case study in Ljubljana metropolitan area. In Advanced Engineering Forum 11: 259-264.

67. Vávra J, Daněk P, Jehlička P (2018) What is the contribution of food selfprovisioning towards environmental sustainability? A case study of active gardeners. Journal of Cleaner Production, 185: 1015-1023.

68. Zasada I, Schmutz U, Wascher D, Kneafsey M, Corsi S, et al. (2019) Food beyond the city-Analysing foodsheds and self-sufficiency for different food system scenarios in European metropolitan regions. City Culture and Society 16: 25-35.

69. Trimmer J T, Guest J S (2018) Recirculation of human-derived nutrients from cities to agriculture across six continents. Nature Sustainability 1(8) 427-435.

70. Kriewald S, Pradhan P, Costa L, Ros A G C, Kropp J P (2019) Hungry cities: how local food self-sufficiency relates to climate change, diets, and urbanisation. Environmental Research Letters 14(9): 094007.

71. Serra P, Saurí D, Salvati L (2018) Peri-urban agriculture in Barcelona: outlining landscape dynamics vis à vis socio-environmental functions. Landscape Research 43(5): 613-631.

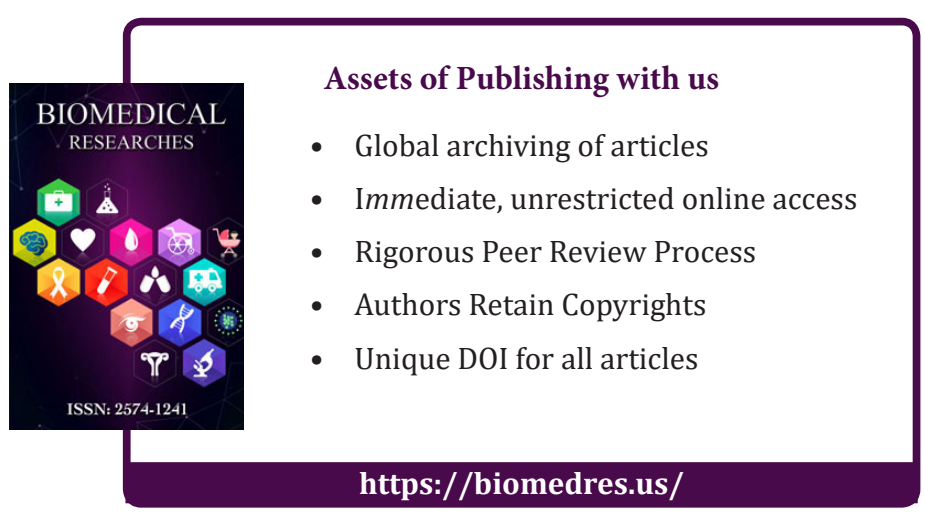

Copyright@ Jean Pierre Enriquez | Biomed J Sci \& Tech Res | BJSTR. MS.ID.005061. 